\title{
Etanolin valmistuksen kasvihuonekaasutaseet
}

\author{
Sampo Soimakallio ${ }^{1)}$, Eemeli Tsupari1 ${ }^{1)}$, Tuula Mäkinen ${ }^{1)}$, Katri Pahkala ${ }^{2)}$, Hannu Mikkola ${ }^{3)}$ \\ 1) Valtion teknillinen tutkimuskeskus (VTT), Vuorimiehentie 5, PL 1000, 02044 VTT, \\ etunimi.sukunimi@vtt.fi \\ ${ }^{2)}$ Maa-ja elintarviketalouden tutkimuskeskus (MTT), 31600 Jokioinen, etunimi.sukunimi@mtt.fi \\ ${ }^{3)}$ Helsingin yliopisto, Koetilantie 3, 00014 Helsingin yliopisto, hannu.j.mikkola@ helsinki.fi
}

Ilmastonmuutoksen hillitseminen on haastava mutta tärkeä tavoite. Siihen pyritään liikenteen osalta mm. lisäämällä biopolttoaineiden osuutta tieliikenteen polttoaineiden kulutuksessa. Liikenteen biopolttoaineiden tuotannon kasvihuonekaasupäästöt riippuvat monista eri tekijöistä, kuten käytettävistä raaka-aineista, tuotantomenetelmistä, lannoitteiden tarpeesta, maankäytön muutoksista ja prosessin tarvitsemasta energiasta ja ne voivat vaihdella merkittävästi eri raaka-aineiden ja tuotantoketjujen välillä.

Etanolin tuotannon kasvihuonekaasupäästöihin sisältyy merkittäviä epävarmuuksia ja herkkyyksiä. Tulosten kannalta keskeisimpiä epävarmuustekijöitä ovat maaperän typpioksiduulipäästöt, lannoitteen valmistuksen päästöt, muutokset maaperän hiilitaseissa ja prosessissa syntyvien sivutuotteiden, kuten sähkön ja/tai lämmön ja valkuaisrehun korvaushyödyt. Parametrien epävarmuudet ja herkkyydet on pyritty huomioimaan käyttämällä apuna todennäköisyyspohjaista mallinnusta.

Ohraetanolin tuotannon ja käytön kasvihuonekaasupäästöt ovat hyvin todennäköisesti suuremmat fossiilisen bensiinin, jonka käyttöä etanolilla on mahdollista korvata. Etanolin tuotannon suuret päästöt johtuvat ennen kaikkea lannoitteiden valmistuksen ja erityisesti käytön aiheuttamista typpioksiduulipäästöistä sekä etanolin prosessoinnissa syntyvistä päästöistä. Suomessa viljan viljelyn lannoituksessa tarvittavan typen määrä on satotasoon nähden suhteellisen suuri. Ohran eri viljelyketjujen vaikutus kasvihuonekaasupäästöihin tuotettua etanolimäärää kohden oli suhteellisen vähäinen (alle $10 \%$ ).

Alustavien arvioiden mukaan näyttäisi siltä, että oljen korjaaminen samalta pellolta korkeintaan joka toinen vuosi ei vaikuttaisi merkittävästi viljelyketjun kasvihuonekaasutaseeseen biomassasaantoa kohden. Oljen korjuun aiheuttamat kasvihuonekaasupäästöt ovat todennäköisesti samaa suuruusluokkaa kuin ruokohelven viljelyn ja korjuun päästöt. Näin ollen nykyisistä viljelyketjuista korjattavan oljen tai viljellyn ruokohelven prosessointi etanoliksi vähentää kasvihuonekaasujen päästöjä bensiiniä korvatessaan. On kuitenkin mahdollista, ettei viljan lisäviljely etanoliksi ole kasvihuonekaasupäästöjen vähentämisen kannalta suotuisaa, vaikka oljet korjattaisiin ja poltettaisiin sähköksi ja/tai lämmöksi tai käytettäisiin etanoliksi korvaamaan päästöintensiivisempiä polttoaineita.

Asiasanat: ilmastonmuutos, kasvihuonekaasu, biopolttoaine, etanoli 


\section{Johdanto}

Ilmastonmuutos on vakava maailmanlaajuinen uhka, jonka hillitsemiseen pyritään mm. vähentämällä ns. kasvihuonekaasujen päästöjä. Noin $13 \%$ maailmanlaajuisista kasvihuonekaasujen päästöistä aiheutuu liikenteestä, mutta liikenteen päästöjen arvioidaan olevan kasvussa (IPCC 2007). Liikenteen vaikutuksia kasvihuonekaasujen päästöihin pyritään hillitsemään muun muassa lisäämällä biopolttoaineiden osuutta polttoaineen kulutuksessa. Biopolttoaineiden tuotannon päästöt voivat puolestaan linkittyä joko suoraan tai epäsuorasti sekä maatalouteen että metsien raivaamiseen viljelysmaiksi. Näiden sektoreiden yhteensä aiheuttamat päästöt ovat maailmanlaajuisesti n. $30 \%$ (IPCC 2007).

EU:n direktiivillä 2003/30/EY pyritään edistämään biomassasta tuotettujen biopolttoaineiden ja muiden uusiutuvien polttoaineiden käyttöä dieselöljyn tai bensiinin korvaamiseksi jäsenmaiden tieliikenteessä. Edistämisen ensisijaisena tavoitteena on vähentää kasvihuonekaasujen päästöjä ja lisätä EU:n energia-omavaraisuutta. Direktiivissä em. fossiilisille polttoaineille vaihtoehtoisten polttoaineiden ohjeelliseksi kansalliseksi viitearvoksi asetettiin polttoaineiden energiasisällöstä laskettuna $2 \%$ vuonna 2005 ja 5,75 \% vuonna 2010. EU:n komission Euroopan energiapolitiikkaa ((COM/2007) 1 final), uusiutuvan energian käyttöä ((COM(2006) 848 final) ja biopolttoaineiden edistämistä ((COM/2006) 845 final) koskevissa tiedonannoissaan EU:n komissio ehdottaa biopolttoaineille sitovaa $10 \%$ :n minimitavoitetta kaikesta liikennepolttoaineesta vuonna 2020. Lisäksi on määritelty, että biopolttoaineen tulee olla kestävällä pohjalla tuotettua riippumatta siitä, onko kyseessä EU:n sisällä vai ulkopuolella tuotettu polttoaine.

Liikenteen biopolttoaineiden tuotannon kasvihuonekaasupäästöt riippuvat monista eri tekijöistä, kuten käytettävistä raaka-aineista, tuotantomenetelmistä, lannoitteiden tarpeesta, maankäytön muutoksista ja prosessin tarvitsemasta energiasta ja ne voivat vaihdella merkittävästi eri raaka-aineiden ja tuotantoketjujen välillä.

Suomessa viljeltävän ohran jyvistä valmistettavan etanolin kasvihuonekaasutaseita tarkasteltiin VTT:n ja MTT:n yhteisessä Tekesin ClimBus-ohjelmaan kuuluneessa BIOGHG-projektissa (Mäkinen et al. 2006) ja sen jatkotöissä (Soimakallio et al. 2007a ja b). VTT:n ja MTT:n AGROETA-projektissa (Von Weymarn 2007) tarkasteltiin etanolin valmistusta maatalouden selluloosavirroista (olki ja ruokohelpi) ja niitä vastaavia kasvihuonekaasutaseita arvioitiin VTT:n omarahoitteisessa BIOSYS-projektissa. Tässä artikkelissa esitetyt tulokset jyvä-, olki- ja ruokohelpietanolin kasvihuonekaasutaseista perustuvat edellä mainituissa hankkeissa tehtyihin laskelmiin.

\section{Menetelmät}

Suomessa viljeltävän ohran jyvistä valmistettavan etanolin kasvihuonekaasutaseita tarkasteltiin VTT:n ja MTT:n yhteisessä Tekesin ClimBus-ohjelmaan kuuluneessa BIOGHG-projektissa (Mäkinen et al. 2006) ja sen jatkotöissä (Soimakallio et al. 2007a ja b). Samoissa hankkeissa tarkasteltiin myös muiden Suomeen laajamittaiseen tuotantoon teknisesti ja kotimaisen raaka-aineen saatavuuden näkökulmasta soveltuvien liikenteen biopolttoaineiden kasvihuonekaasutaseita (rypsipohjaisen biodiesel ja Fischer-Tropsch-diesel metsätähteistä tai ruokohelvestä). Hankkeessa ohran viljelylle mallinnettiin kahdella erilaisella tavoitesatotasolla (3,5 t/ha ja 4,2 t/ha) kuusi erilaista ketjua, jotka poikkesivat $\mathrm{mm}$. maanmuokkausmenetelmien (kyntö, sänkimuokkaus, suorakylvö) ja viljan kuivauksen (lämminilmakuivaus, ilmatiivissäilöntä) suhteen (Mäkinen et al. 2006). Vastaavasti ruokohelvelle mallinnettiin yhdelle tavoitetasolle $(7,5 \mathrm{t} / \mathrm{ha})$ ja viljelykäytännölle kaksi vaihtoehtoista korjuumenetelmää (irtokorjuu ja paalaus).

BIOGHG-hankkeessa maatalousmaiden vertailutilanteeksi on oletettu viljelemätön pelto, riippumatta siitä, perustettaisiinko biopolttoaineen tuotanto viljellylle vai viljelemättömälle pellolle. Tämä johtuu toisaalta siitä, että biopolttoaineiden raaka-aineiden tuotanto tulisi todennäköisesti enimmäkseen keskittymään kesantopelloille ja toisaalta viljelemättömyys on todennäköisin vaihtoehto viljelylle alueilla, joissa viljan tuotantoedellytykset ovat heikot. Lisäksi jo muussa käytössä olevien peltojen 
käyttäminen bioenergiantuotantoon aiheuttaisi todennäköisesti viljelyn siirtymistä alueelta toiselle, mikä puolestaan aiheuttaisi hankalasti arvioitavia seurannaisvaikutuksia.

Ohraetanolin tuotannon yhteydessä syntyvän valkuaisrehun oletettiin korvaavan USA:sta tuotavaa soijarehua rehujen valkuaispitoisuudet huomioiden. Korvauksen vuoksi soijarehun viljelyssä ja kuljetuksissa syntyvät kasvihuonekaasupäästöt vähennettiin jyväetanolin kasvihuonekaasupäästöistä.

Oljen korjuun vaikutuksia viljelysmaan kasvihuonekaasupäästöihin ja satotasoon arvioitiin saatavilla olevien kansallisten ja kansainvälisten selvitysten perusteella VTT:n omarahoitteisessa BIOSYShankkeessa. Oljen korjuun vertailutilanteena käytettiin tyypillistä nykyistä vaihtoehtoa silputa ja muokata oljet viljelysmaahan. Kuivikkeena käytettävän oljen ohjautuminen etanolin valmistukseen nähtiin epätodennäköiseksi korvaavien kuivikkeiden kustannusten takia, eikä kuivikkeen korvaamisen vaikutuksia siksi ole huomioitu.

Olki- ja ruokohelpietanolin prosessoinnissa etanolisaanto on noin viidennes prosessiin syötetystä raaka-aineen kuiva-ainemäärästä. Sivuvirtoina syntyy kiintoainetta, joka on oletettu poltettavan prosessissa tarvittavaksi energiaksi (Von Weymarn 2007). Koska syntyvän kiintoaineen määrä on etanolisaantoon verrattuna suuri ja lämpöarvo suhteellisen korkea, on prosessi energiataloudellisesti yliomavarainen. Kiintoainesivuvirta on oletettu hyödynnettävän kokonaisuudessaan lähtökohtaisesti prosessin tarvitsemaksi energiaksi ja ylijäämäosuudeltaan edelleen sähköksi.

Määritellyissä tarkastelurajoissa laskettiin biopolttoaineiden raaka-aineiden tuotannossa, ja kuljetuksessa sekä biopolttoaineiden prosessoinnissa, jakelussa ja annostelussa syntyvät kasvihuonekaasujen päästöt, jotka johtuvat eri vaiheiden energiankulutuksesta, tarvittavien kemikaalien valmistuksesta ja kuljetuksesta sekä maaperän prosesseista. Kasvihuonekaasupäästöt laskettiin sekä etanolin energiasisältöä kohden että henkilöautolla ajettua kilometriä kohden, jotta vertailu korvattavaan bensiiniin voitiin suorittaa objektiivisemmin. Bensiinin korvauksesta syntyvän suhteellisen päästövähennyksen lisäksi laskettiin suhteellinen päästövähennys kulutettua biohiiltä kohden, jotta prosessien tehokkuus biomassan hyödyntäjinä kasvihuonekaasupäästöjen vähentämisessä kuvautuisi paremmin.

Tulokset on laskettu erikseen kaikille tarkastelluille etanolivaihtoehdoille, mutta vertailun vuoksi on myös laskettu tilanne, jossa samoilta pelloilta käytettäisiin sekä jyvät että oljet etanoliksi. Jyvät ja oljet eivät kuitenkaan sovellu samaan etanolintuotantoprosessiin, vaan tällöin tarvittaisiin vähintään kaksi erityyppistä tuotantoyksikköä (Mäkinen et al. 2006, Von Weymarn 2007).

Tarkasteluissa kasvihuonekaasuista huomioitiin Kioton pöytäkirjan alaisuuteen kuuluvat hiilidioksidi $\left(\mathrm{CO}_{2}\right)$, metaani $\left(\mathrm{CH}_{4}\right)$ ja typpioksiduuli $\left(\mathrm{N}_{2} \mathrm{O}\right)$. Tarkastellut kasvihuonekaasut muunnettiin hiilidioksidiekvivalenteiksi niiden 100 vuoden lämmitysvaikutuksen perusteella $\left(\mathrm{GWP}_{100}\right.$-menetelmä) käyttäen IPCC:n (1996) oletuskertoimia hiilidioksidille (1), metaanille (21) ja typpioksiduulille (310).

\section{Tulokset ja tulosten tarkastelu}

Ohran viljelyn kasvihuonekaasupäästöt aiheutuvat enimmäkseen lannoitetypen valmistuksessa ja käytössä syntyvistä typpioksiduulipäästöistä $\left(\mathrm{N}_{2} \mathrm{O}\right)$. Lisäksi maaperän hiilivaraston pieneneminen perinteisessä maanmuokkauksessa voi olla suhteellisen merkittävä tekijä erityisesti lyhyillä tarkastelujaksoilla. Pitkäaikaisessa viljelyssä sen merkitys kuitenkin ajan myötä vähenee. Viljelyn koneiden käyttöenergiasta sekä siementen kuivauksesta ja kuljetuksesta aiheutuvat päästöt ovat todennäköisesti selvästi edellä mainittuja tekijöitä vähäisemmät. Ohran eri viljelyketjujen vaikutus kasvihuonekaasupäästöihin tuotettua etanolimäärää kohden on suhteellisen vähäinen (alle $10 \%$ ).

Ruokohelven viljelyn kasvihuonekaasupäästöt ovat energiasisältöä kohden ilmaistuna todennäköisesti huomattavasti ohran viljelyn päästöjä vähäisemmät. Tämä johtuu ennen kaikkea siitä, että ruokohelven vaatima typpilannoitus satotasoa kohden on merkittävästi ohraa pienempi. 
Oljen korjuu pelloilta voi vaikuttaa pellon kasvihuonekaasutaseeseen sekä typpioksiduulin $\left(\mathrm{N}_{2} \mathrm{O}\right)$ että hiilidioksidin $\left(\mathrm{CO}_{2}\right)$ osalta monimutkaisten prosessien seurauksena. Vaikutusten suuruusluokka ja suunta ovat verrattain huonosti tunnettuja, sillä viljelysmaan typpioksiduulipäästöihin ja hiilitaseeseen vaikuttaa hyvin moni tekijä, kuten maaperän laatu, lämpötila, sademäärä, lannoitusmäärä ja viljelykäytäntö.

Useiden mittausten (mm. Malhi et al. 2006; Malhi ja Lemke 2007; Gregorich et al. 2005) mukaan pellon $\mathrm{N}_{2} \mathrm{O}$-päästöt pienenevät kun olki korjataan pois. Yksinkertaistettuna tämä perustuu pienempään yhtäkkiseen typpilisäykseen pellossa kynnön jälkeen. Tutkimuksissa on yleensä kuitenkin esitetty päästöt peltopinta-alaa kohden laskettuina. Ravinteiden poistuminen ja maan ominaisuuksien muuttuminen oljen korjuun mukana saattaa kuitenkin pienentää saatavaa jyvä- ja olkisatoa jopa niin paljon, että satoa kohden laskettuna $\mathrm{N}_{2} \mathrm{O}$-päästöt saattavat kasvaa verrattuna tilanteeseen, jossa olki kynnetään peltoon. Satotason pienentymistä on mahdollista kompensoida lisäämällä lannoitusmäärää, mutta tällöin lannoituksen valmistuksesta ja käytöstä syntyvät päästöt ovat puolestaan suurempia. Lisääntynyt typpilannoitus lisää selvästi pellon $\mathrm{N}_{2} \mathrm{O}$-päästöjä.

Peltojen $\mathrm{N}_{2} \mathrm{O}$-päästöön vaikuttaa voimakkaasti esimerkiksi sademäärä ja sen ajallinen jakautuminen mm. lannoitukseen nähden. On myös muistettava, että $\mathrm{N}_{2} \mathrm{O}$-päästön edustava mittaaminen pellolta on hankalaa ja mittausten yleistettävyys siten epävarmaa. Esimerkiksi, joidenkin mittausten perusteella $\mathrm{N}_{2} \mathrm{O}$-päästön voisi päätellä kasvavan myös pellon pinta-alaa kohden laskettuna, kun olki korjataan pois.

Suuri osa oljen sisältämästä hiilestä on vapautunut hiilidioksidina oljen lahotessa maaperässä jo vuoden kuluttua kyntämisestä. Osa kasvijätteen hiilestä siirtyy kuitenkin humukseen. Myös humuskerros hajoaa hitaasti, joten maahan kertyvän hiilen määrä on hankala arvioida ja hitaan hajoamisen takia maahan lopulta kertynyt hiilimäärä riippuu myös tarkasteluajasta. Olkien korjuu näyttäisi pienentävän maan hiilivarastoa sadan vuoden tai sitä lyhyemmillä tarkasteluajoilla. Mitä lyhyempi tarkastelujakso, sitä suurempi on oljen korjuusta aiheutuva hiilivaraston pieneneminen viljelyalaa kohden. Se hiilimäärä, mikä olisi olkien kyntämistilanteessa sitoutunut maaperään tarkastelujakson aikana, tulee huomioida kun vastaava hiilimäärä vapautuu hiilidioksidina olkietanolia poltettaessa.

On todennäköistä, että oljen korjuu pienentää jonkin verran pellosta syntyviä typpioksiduulipäästöjä, satotasoa ja maaperään sitoutuvan hiilen määrää peltopinta-alaa kohden tarkasteltuina. Arvioitaessa oljen korjuun vaikutuksia kokonaiskasvihuonekaasutaseeseen, saattavat edellä mainitut tekijät epävarmuudet huomioiden yhdessä joko pienentää tai kasvattaa kasvihuonekaasupäästöjä. On kuitenkin todennäköistä, että oljen korjuun vaikutus kasvihuonekaasupäästöihin on suurin piirtein samaa luokkaa kuin ruokohelven viljelyn ja korjuun päästöt biomassan energiasisältöä kohden.

Suotuisimmillaan olki-/ruokohelpietanolin prosessoinnin kasvihuonekaasutase on silloin, kun koko kiintoainesivuvirta voidaan hyödyntää energiaksi, joka korvaa päästöintensiivisiä polttoaineita sähkön ja/tai lämmöntuotannossa. Tämä korvaushyöty huomioiden etanolin prosessoinnin kokonaiskasvihuonekaasupäästöt tuotettua etanolimäärää kohden voivat olla jopa negatiiviset.

Syötettävän raaka-aineen ja höyryn lisäksi etanolin valmistusprosessissa käytetään merkittävästi myös $\mathrm{mm}$. entsyymejä ja hiivaa. Hiiva kasvatetaan tehtaalla ja sen energiankulutus on verrattain pieni. Entsyymien osalta epävarmuudet ovat suurempia ja niiden tuotanto voi vaikuttaa hieman energia- ja päästötaseisiin.

Oljen tai ruokohelven kuljetusten sekä etanolin jakelun ja annostelun vaikutus kasvihuonekaasupäästöihin on tyypillisesti vähäinen verrattuna lopputuotteella korvattavien fossiilisten polttoaineiden kokonaispäästöihin.

Koska biopolttoaineiden kasvihuonekaasupäästöjen arviointiin liittyy merkittäviä epävarmuuksia, ei tuloksia ole mielekästä esittää yksittäisinä oletusarvoihin perustuvina lukuarvoina. Epävarmuuksien 
hallintaan on käytetty BIOGHG-hankkeen jatkotöissä (Soimakallio et al. 2007a ja b) ja tässä artikkelissa esitetyissä tuloksissa todennäköisyyspohjaista mallintamista Monte Carlo -simuloinnin avulla. Kuvassa 1 on esitetty kasvihuonekaasupäästöjen vähentämisen tehokkuutta mittaava suhteellinen indikaattori todennäköisyysjakaumina tässä artikkelissa tarkastelluille biopolttoainevaihtoehdoille.

Kuvan 1 perusteella ohran jyväetanolin tuotannon ja käytön kasvihuonekaasupäästöt soijarehun korvaushyötyineen ovat hyvin suurella todennäköisyydellä suuremmat kuin bensiinin kasvihuonekaasupäästöt.

Mikäli olki- tai ruokohelpietanolin prosessoinnissa syntyvä kiintoaine hyödynnetään kokonaisuudessaan energiaksi, ovat olki- tai ruokohelpietanolin tuotannon ja käytön kasvihuonekaasupäästöt korvaushyötyineen kokonaisuudessaan puolestaan todennäköisesti hyvin vähäiset tai jopa negatiiviset verrattuna bensiinin tuotannon ja käytön päästöihin. Tulosta tarkasteltaessa on syytä huomioida, että etanolin saanto prosessissa on verrattain alhainen ja noin neljä viidesosaa oljen tai ruokohelven kuiva-aineesta hyödynnetään prosessissa käytettäväksi energiaksi ja myytäväksi sähköksi. Korvaushyötyineen kulutettua biohiiltä kohden olki- tai ruokohelpietanoli ja sen sivutuotteena syntyvä kiintoaine vähentävät kasvihuonekaasupäästöjä todennäköisesti luokkaa 20$40 \%$ (kuva 1). Todennäköisesti suurempi päästövähennys kulutettua biohiiltä kohden saavutetaan kuitenkin korvaamalla päästöintensiivisiä polttoaineita sähkön ja/tai lämmön tuotannossa.

Jos sekä ohran jyvät että olki käytetään etanoliksi, ovat tuotteiden kasvihuonekaasupäästöt todennäköisesti samaa suuruusluokkaa, hieman pienemmät tai hieman suuremmat kuin korvattavalla bensiinillä.

Edellä esitetyt arviot olki- ja ruokohelpietanolin kasvihuonekaasutaseista perustuvat VTT:llä syksyllä 2007 tehtyihin alustaviin arvioihin. Laskelmia tullaan todennäköisesti tarkentamaan vuoden 2008 alkupuolella.

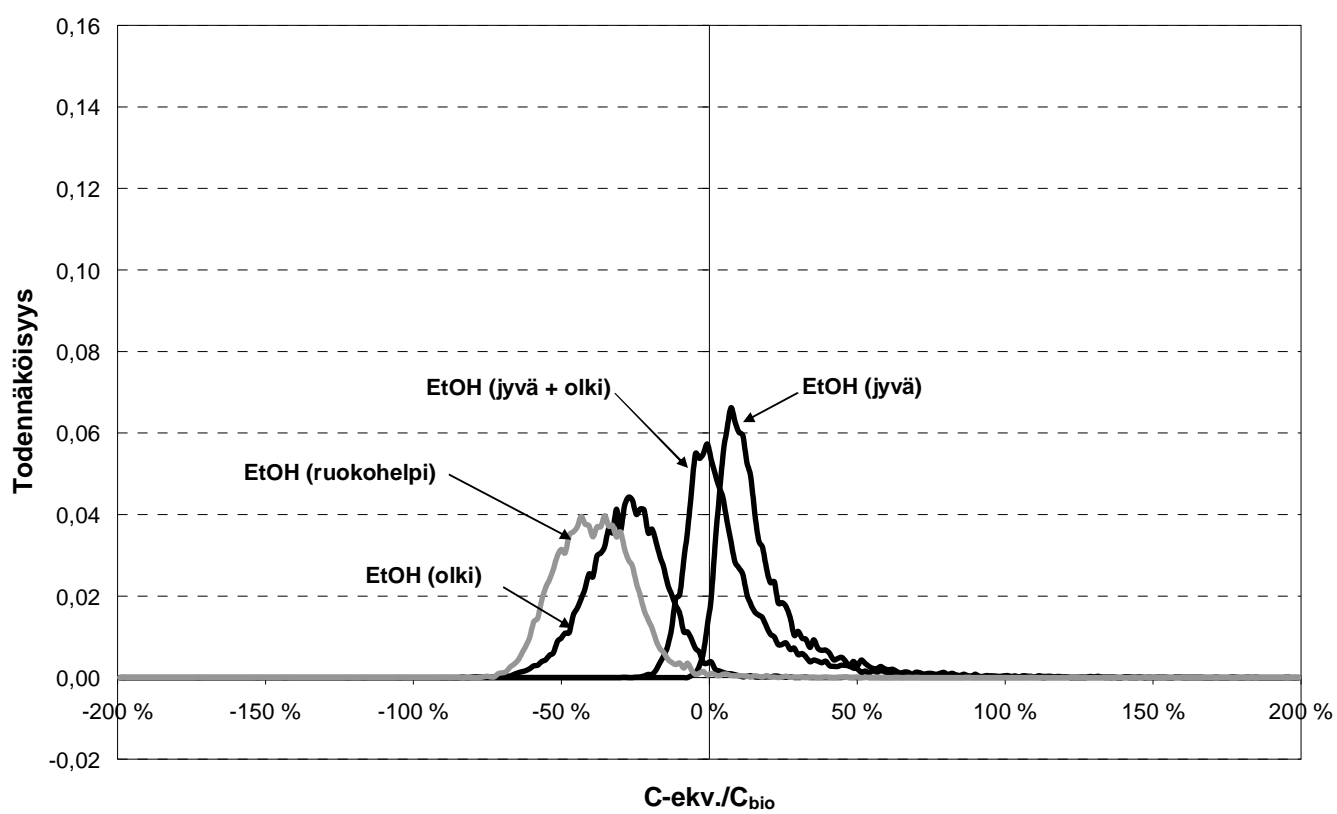

Kuva 1. Ohran jyvä-, olki- ja ruokohelpietanolin suhteellinen tehokkuus kasvihuonekaasupäästöjen vähentämisessä ilmaistuna vähennettynä hiiliekvivalenttina kulutettua biohiiltä kohden bensiiniä korvattaessa. Jyvä- ja olkietanoliyhdistelmässä on oletettu, että olkietanolia tuotetaan niin paljon kuin jyväetanolin tuotantoalalta on olkia saatavissa etanolin tuotantoprosessiin.

\section{Johtopäätökset}


Suomessa ohran viljely etanoliksi ei ole kasvihuonekaasupäästöjen vähentämisen kannalta suotuisa keino. Tämä johtuu ennen kaikkea verrattain alhaisesta satotasosta ja vastaavasti korkeasta typpilannoitteen tarpeesta moniin suotuisampiin viljelyolosuhteisiin verrattuna.

Olkien hyötykäyttö vaikuttaisi olevan suotuisa keino kasvihuonekaasupäästöjen vähentämisen kannalta. On kuitenkin mahdollista, ettei viljan lisäviljely etanoliksi ole kasvihuonekaasupäästöjen vähentämisen kannalta siltikään suotuisaa, vaikka oljet korjattaisiin ja poltettaisiin energiaksi korvaamaan päästöintensiivisempiä polttoaineita. Sen sijaan oljen korjaaminen nykyisistä viljelyketjuista ja hyötykäyttäminen energiaksi korvaamaan päästöintensiivisempiä polttoaineita vaikuttaisi olevan kasvihuonekaasupäästöjen vähentämisen kannalta suotuisaa. Biomassan energiasisältöä kohden ruokohelven viljelyn ja korjuun kasvihuonekaasupäästöt ovat todennäköisesti samaa suuruusluokkaa kuin oljen korjuun vaikutukset, joten myös ruokohelven viljely ja hyötykäyttö energiaksi vaikuttaisivat olevan suotuisia keinoja kasvihuonekaasupäästöjen vähentämisen näkökulmasta.

\section{Kirjallisuus}

Commission of the European Communities 2007. Communication from the Commission to the European Council and the European Parliament - An Energy Policy for Europe. COM(2007) 1 final. Brussels 10.1.2007.

Commission of the European Communities 2007. Communication from the Commission to the Council and the European Parliament - Renewable Energy Road Map; Renewable energies in the 21st century: building a more sustainable future. $\operatorname{COM}(2006) 848$ final. Brussels 10.1.2007.

Commission of the European Communities 2007. Communication from the Commission to the Council and the European Parliament - Biofuels Progress Report; Report on the progress made in the use of biofuels and other renewable fuels in the Member States of the European Union. COM(2006) 845 final. Brussels 10.1.2007.

Gregorich, E. G., Rochette, P., VandenBygaart, A. J. ja Angers, D. A. 2005/2007. Greenhouse gas contributions of agricultural soils and potential mitigation practices in Eastern Canada. Soil and Tillage Research 83:1, s. 53-72. Korjaus: Soil and Tillage Research 94:1(2007), s. 262-263.

IPCC. 1996a. Climate Change 1995. The Science of Climate Change. Contribution of Working Group I to the Second Assessment Report of the Intergovernmental Panel on Climate Change. Great Britain. 572 p.

IPCC 2007. Climate Change 2007. Mitigation of climate change. Working Group III Contribution to the Fourth Assessment Report of the Intergovernmental Panel on Climate Change. Summary for Policymakers and Technical Summary. Intergovernmental Panel on Climate Change 2007. 108 p.

Malhi, S. S., Lemke, R., Wang, Z. H. ja Chhabra, B. S. 2006. Tillage, nitrogen and crop residue effects on crop yield, nutrient uptake, soil quality, and greenhouse gas emissions. Soil and Tillage Research 90:1-2, s. 171-183.

Malhi, S. S. ja Lemke, R. 2007. Tillage, crop residue and N fertilizer effects on crop yield, nutrient uptake, soil quality and nitrous oxide gas emissions in a second 4-yr rotation cycle. Soil and Tillage Research. Painossa. doi:10.1016/j.still.2007.06.011 
Mäkinen, T., Soimakallio, S., Paappanen, T., Pahkala, K., Mikkola, H. 2006. Liikenteen biopolttoaineiden ja peltoenergian kasvihuonekaasutaseet ja uudet liiketoimintakonseptit. VTT Tiedotteita 2357. Espoo, 2006. 134 s. + liitt. 19 s.

Soimakallio, S., Mäkinen, T., Paappanen, T., Ekholm, T. , Pahkala, K., Mikkola H. 2007a. Greenhouse Gas Balances for Biomass-Based Transportation Fuels and Agrobiomass in Finland. Proceedings of 15th European Biomass Conference \& Exhibition from Research to Market deployment, ICC Berlin 7-11.5.2007. $6 \mathrm{p}$.

Soimakallio, S., Mäkinen, T., Ekholm, T. 2007b. Greenhouse Gas Balances of Transportation Biofuels in Finland - Dealing with the Uncertainties. Presentation in International Energy Workshop 2007. Stanford University, Stanford, California, 25-27 June 2007.

Von Weymarn 2007. Bioetanolia maatalouden selluloosavirroista. (Toim. Niklas Von Weymarn). VTT Tiedotteita 2412. Espoo, 2007. $44 \mathrm{~s}$. http://www.vtt.fi/inf/pdf/tiedotteet/2007/T2412.pdf 